\title{
Investigating the Moderating Effect of Hospital Public Image on Loyalty
}

\author{
Arlina Nurbaity Lubis \\ Department of Management \\ Faculty of Economic and Business \\ Universitas Sumatera Utara \\ Medan, Indonesia \\ arlinalubis10@gmail.com
}

\author{
Prihatin Lumbanraja \\ Department of Management \\ Faculty of Economic and Business \\ Universitas Sumatera Utara \\ Medan, Indonesia \\ titinlumbanraja@yahoo.com
}

\author{
Rodiah Rahmawaty Lubis \\ Department of General Medic \\ Faculty of Medical Science \\ Universitas Sumatera Utara \\ Medan, Indonesia \\ rahma.lubis@yahoo.com
}

\begin{abstract}
A growing concern for people's health has brought out a need of a better healthcare. People will be more selective to use a healthcare services. The seed of service repurchase for healthcare started from their loyalty toward the healthcare services provider. People went through service experience to evaluate their satisfaction toward service given to them. Naturally, people will be satisfied if they had experienced the services beyond their expectation. However, public opinion to the healthcare services provider affect their choice. This research aimed to evaluate the new dimension of healthcare services on their satisfaction and loyalty. In addition, this research also evaluated the moderating effect of hospital image while creating people's loyalty in private hospital. This research took place in three private hospital in Medan. A number of 150 inpatients participated in this research. Data were collected through questionnaires and structured interview. The data was analyzed using second-order partial least squares. This research showed a positive and significant effect of service quality toward inpatients' satisfaction.Loyalty can only affect indirectly through satisfaction. The presence of hospital images slightly strengthen inpatients' loyalty toward healthcare services provider. However, it is insignificant. This study suggested that hospital management should focused on improving their patient educational services and their staff professionalism as both services perceived higher on service quality.
\end{abstract} Loyalty

Keywords- Hospital Images, Service Quality, Satisfaction,

\section{INTRODUCTION}

Demand for private healthcare services has been increasing for last decade, especially in Medan, North Sumatera. People's trust toward private healthcare services provider keeps on growing. They believed that the private healthcare services mostly better than the government one. On a single glance, people will mostly perceived that the private one better than the government one. Most people believed that private healthcare services had more sophisticated and modern medical equipment. To put it simply, they private healthcare service provider gave a better performance.

Healthcare service industry, like other services, required a lot of interaction with its customer to determine their successfulness [1]. The core for their success factor was related to the perceived service quality, satisfaction, and customer loyalty. Even though most people believed that the private will perform better, the customer behavior is dynamic. People's preference may change overtime.

In order to maintain the existing customer behavior, it is important to achieve the customer loyalty. According to the previous study on medical field, customer loyalty or patient loyalty can be achieved according to their experience while consuming the services [2]. Thus, it is related to the service quality itself. However, according to marketing concept, service consumption and evaluation will ended up on dissatisfied, satisfied, or delighted. A loyal behavior can only occurred on satisfied and delighted customer [3].

Parasuraman et al. [4] already stated one's service quality become a key success factor for sustainability in a competitive market. Service quality is generated through service delivery, the routine that delivered for each customer. We should keep a note that the key success factor for service quality was not the procedure or the operation itself, but the perceived service quality on customer's perspective [5]. Thus, it is important to evaluate the services that perceived by the customer. The perceived service quality will affect their satisfaction level $[6,7]$. The significance for these finding is the rapid change for recent years' hospital service quality. They steadily improve the services to be better than another competitor on the field.

Bowen and Chen [8] warned that satisfying the customer was not enough, they should be delighted with the services to generate their loyal behavior. Satisfy the customer and brought up their loyalty is actually not an option for services provider, especially the private one, as people will be more aware. It is a must, a task to carry out if they were willing to create a competitive advantage and sustainable growth for a long term [9].

As we talked about today's society, public brand image became an important factor to be evaluated. Hsieh and Li's study [10] showed that brand image played as moderating variable which strengthen the effect of public relation's effectiveness. Chung et al.'s study [11] also empirically showed that a favorable companies with a good brand image will perceived better on delivering CSR. Hospital manager also 
spend a lot of money to build the corporate's image. They do not wish that people negatively perceived themselves. However, it is still unclear whether the image actually will strengthen people's loyalty or not.

This research was aimed to investigate the effect of perceived service quality on patients' satisfaction and loyalty, as well as the important aspect of service quality on patients' perspective for private healthcare services provider in Medan. Moreover, we investigate the role of brand image in relationship between perceived services quality with satisfaction and loyalty.

\section{LITERATURE REVIEW}

\section{A. Benefit of Loyal Patients and how to measure it}

Marketers agreed to the term that one of final goal of marketing activities was achieving customer loyalty [12]. It was the source of company's long-life profit as well as the source of sustainable competitive advantage [13]. Wright et al. illustrated that loyalty, in service context, described as their behavior and willingness to repurchase the services in the future repeatedly. They will also voluntarily recommend their friend or other to the product (or service provider). Loyalty is more than a consistent repurchase behavior.

A loyal patient will not easily swayed to other healthcare provider. Thus, a loyal patient will be more likely to use our healthcare services when they or their family need it. In a nut shell, loyal patient will retain themselves to use our services in the near future. Based on previous studies, it is around fifteen times more expensive to gain a new customer than maintaining the existing one [14]. Retaining the customer become more strategic way to achieve sustainability for a long term.

Researcher agreed on how a loyalty reflected toward customers' behavior. Firstly, they will repurchase or reuse the product and services (repurchase). Secondly, they will be harder to shift toward other product (retain). Lastly, they will recommend the product to other, family, friends, even collage (recommend).

\section{B. Relationship of Satisfaction and Loyalty}

Satisfaction was not inherent with the products or services but their perception toward its attribute [15]. Naturally, each person's satisfaction level for the same service will vary according to each individual [16]. The concept of satisfaction related to customers' evaluation toward their previous consumption, either product or service [17].The customer will compare their previous experience with the expectation. They will be satisfied if at least their consumption meets their expectation. In contrast, they will be dissatisfied if it can not meet their expectation. Lovelock and Wright explained that there is a huge difference in loyalty behavior on the one that satisfied with the one that extremely satisfied (delighted). Thus, we expect the positive effect of customer satisfaction to their loyalty.

\section{Service Quality and Patients' Satisfaction}

Parasuraman [18] stated that service quality is a multidimension concept. It should not be explained separately. According to Parasuraman, service quality had five dimensions: (1) tangibility, (2) empathy, (3) responsiveness, (4) reliability, and (5) assurance. Lubis's study [19] expanded the dimension in accordance with the healthcare practice in North Sumatera and summarized ten dimension of healthcare service quality: (1) patient educational services, (2) staffprofessionalism, (3) food aspect, (4) assurance, (5) responsiveness and convenience services, (6) empathy, (7) cleanliness, (8) well-educated staff, (9) people trust-gaining services, and (10) reliable services.

Customers' satisfaction was evaluated based on their experience toward the given services. There was a direct relationship between the perceived service quality and their satisfaction. According to our literature, a better service lead to satisfaction. Jiang and Wang's Study [20] showed that on a utilitarian services such as healthcare services, it is important to show the pleasure of good services than arousing the satisfaction itself. Ahmed et al. [21] empirically showed that the service provided by healthcare provider will positively affect their satisfaction and loyalty.

\section{Previous role of brand image}

Brand image lied on people's mind. It based on both their capabilities and more emotional aspect [22]. It represent the corporate on public's mindset [23]. Chung et al. evaluated the moderating effect of brand image on CSR and Loyalty. Indeed, the brand image strengthen people's acceptance toward the CSR act on their loyalty. Our present work investigate the moderating effect based on the perceived service quality to their satisfaction and loyalty.

\section{RESEARCH METHOD}

\section{A. Research Design}

The research was conducted on August 2017. We focused the study on private healthcare service provider in Medan. We researched on RS Stella Maris, RS Elisabeth, and RS Columbia-Asia. A number of fifty inpatients for each hospital have participated in this research. The data were collected through self-administering questionnaires. The questionnaires were based on the previous work related to ten-dimension of hospital service quality.

\section{B. Data Analysis Method}

The data were analyzed using Smart-PLS [24]. In order to evaluate the importance of each aspect of perceived service quality, a second-order model was proposed in this study. The proposed model summarized in Figure 1. The model was evaluated for its validity and reliability based on partial-leastsquared criterion. 


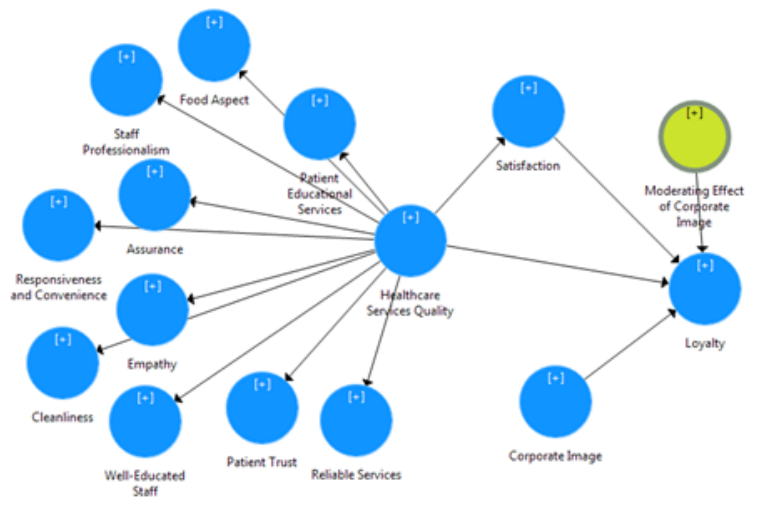

Figure 1. Research Model

\section{Evaluating the Moderation Role}

In order to achieve the robust estimate, we used two-stage approach to estimate the effect of each variable in model. The brand image used as both independent and moderating variables. We evaluated the moderation effect as pure moderator, quasi-moderator, or not a moderator based on its significance.

\section{RESULT AND DISCUSSION}

\section{A. The Current Situation}

We evaluated the current situation of each construct based on its average value ( $\max$ scale of 5). The gap between maximum and minimum value can explain the variation of each inpatients' respond within our research construct.

Table 1. Descriptive Result

\begin{tabular}{|l|r|r|l|}
\hline \multicolumn{1}{|c}{ Table 1. Descriptive Result } \\
\hline Construct & \multicolumn{1}{c|}{ Average } & \multicolumn{1}{l|}{ Max } & \multicolumn{1}{l|}{ Min } \\
\hline Perceived Service Quality & & & \\
\hline Assurance & 4.14 & 5.00 & 2.80 \\
\hline Cleanliness & 4.12 & 5.00 & 1.67 \\
\hline Empathy & 3.92 & 5.00 & 2.33 \\
\hline Food Aspect & 4.03 & 5.00 & 1.67 \\
\hline $\begin{array}{l}\text { Patient } \\
\text { Services }\end{array}$ & 3.91 & 4.92 & 2.23 \\
\hline Patient Trust & 3.87 & 5.00 & 2.67 \\
\hline $\begin{array}{l}\text { Reliable Service } \\
\text { Convenience }\end{array}$ & 3.82 & 5.00 & 2.67 \\
\hline $\begin{array}{l}\text { Staff Professionalism } \\
\text { and }\end{array}$ & 3.98 & 5.00 & 2.00 \\
\hline Well-Educated Staff & 4.09 & 5.00 & 2.17 \\
\hline $\begin{array}{l}\text { Corporate Image } \\
\text { Satisfaction }\end{array}$ & 3.05 & 5.00 & 2.05 \\
\hline $\begin{array}{l}\text { Loyalty } \\
\text { Tabl 1 }\end{array}$ & 3.76 & 4.64 & 1.57 \\
\hline
\end{tabular}

Table 1 showed that on average the level of inpatients' satisfaction and loyalty level was quite high. Most of the service quality aspect also perceived well to the inpatients (cutoff value of 3.40). The highest value that perceived well on the patients' perspective was their assurance level. They commonly believed that private healthcare services assuring themselves for the services given. Also, the place's cleanliness was always in check. They keep the ward clean all the time. However, there were several inpatients that perceived most aspect negatively. The existence of minimum value under 2.60 point leave a lot of room for improvement. Overall, all aspect of our variables had already been perceived well.

\section{B. Validity and Reliability Model}

The PLS model evaluation require validity and reliability test for the given model [25]. The indicator for each construct should be able to explain its variables well according to the its average variance extracted (AVE) and composite reliability. The AVE value for each construct should be more than 0.5 to achieve the validity model. The composite reliability value for each construct should be more than 0.7 to achieve the reliability model. Validity and reliability index value based on AVE and composite reliability were summarized on Table 2 as follow:

Table 2. Validity and Reliability Valuation PLS Model

\begin{tabular}{|l|r|r|}
\hline \multicolumn{1}{|c|}{ Construct } & \multicolumn{1}{c|}{ AVE } & Composite Reliability \\
\hline Assurance & 0.538 & 0.853 \\
\hline Cleanliness & 0.745 & 0.897 \\
\hline Corporate Image & 0.586 & 0.951 \\
\hline Empathy & 0.738 & 0.894 \\
\hline Food Aspect & 0.872 & 0.953 \\
\hline Loyalty & 0.613 & 0.967 \\
\hline Patient Educational Services & 0.615 & 0.954 \\
\hline Patient Trust & 0.727 & 0.889 \\
\hline Reliable Service & 0.643 & 0.843 \\
\hline Responsiveness and Convenience & 0.734 & 0.917 \\
\hline Satisfaction & 0.760 & 0.950 \\
\hline Staff Professionalism & 0.709 & 0.935 \\
\hline Well-Educated Staff & 0.597 & 0.855 \\
\hline
\end{tabular}

Table 2 summarized both validity and reliability evaluation for the given model. The cut-off value for AVE is 0.5 and 0.7 for composite reliability. Both validity and reliability criteria had been fulfilled, thus it is permitted to evaluate the model furthermore.

Our research evaluated the importance of each dimension in perceived service quality. A ranked order of importance based on their regression weight of second order construct was used to summarized the level of magnitude of each dimension. 
Figure 2 Showed the ranked order.

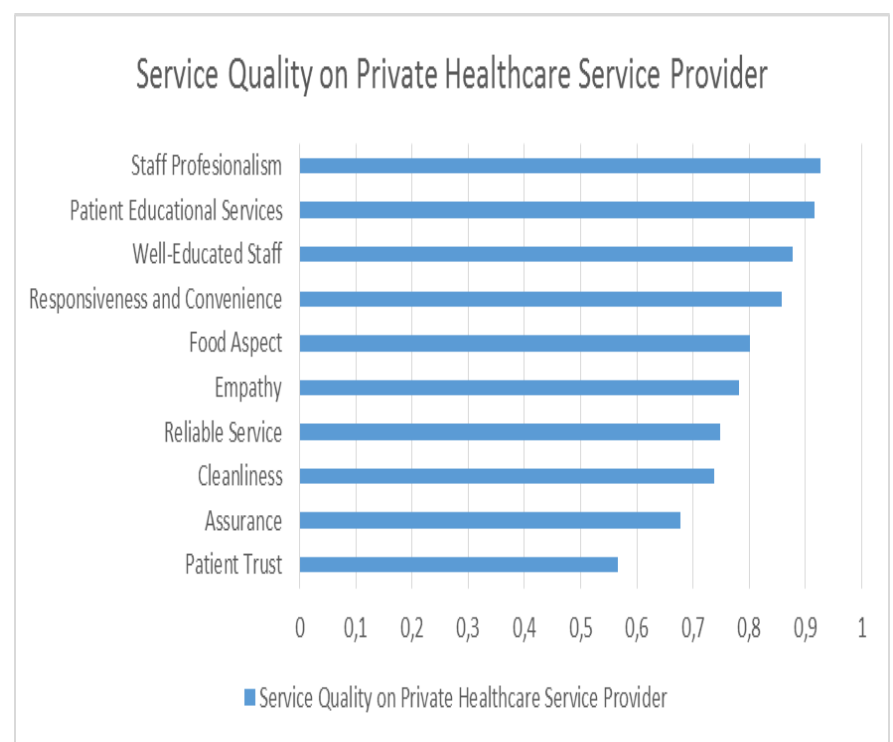

Table 3. Path Estimate Model

\begin{tabular}{|l|l|l|r|r|c|}
\hline $\begin{array}{l}\text { Independent } \\
\text { Variable }\end{array}$ & $\begin{array}{c}\text { Dependent } \\
\text { Variable }\end{array}$ & Mediator & $\begin{array}{c}\text { Direct } \\
\text { Effect }\end{array}$ & $\begin{array}{c}\text { Indirect } \\
\text { Effect }\end{array}$ & $\begin{array}{c}\text { Total } \\
\text { Effect }\end{array}$ \\
\hline $\begin{array}{l}\text { Service } \\
\text { Quality }\end{array}$ & Satisfaction & - & $0.758^{*}$ & - & $0.758^{*}$ \\
\hline $\begin{array}{l}\text { Service } \\
\text { Quality }\end{array}$ & Loyalty & Satisfaction & -0.019 & $0.190^{*}$ & 0.171 \\
\hline Satisfaction & Loyalty & - & $0.250^{*}$ & - & $0.250^{*}$ \\
\hline $\begin{array}{l}\text { Corporate } \\
\text { Image }\end{array}$ & Loyalty & - & $0.756^{*}$ & - & $0.756^{*}$ \\
\hline $\begin{array}{l}\text { Service } \\
\text { Image }\end{array}$ & Loyalty & - & 0.085 & - & 0.085 \\
\hline
\end{tabular}

Table 3 showed that perceived service quality actually can not directly affect the inpatients' loyalty. It can only achieved through their satisfaction. Even though the previous study showed that the magnitude of customer loyalty is greater than customer satisfaction, however, our research showed that both are important. In order to achieve customer behavior, their satisfaction state is needed. Our finding suggest that there will be no loyalty achieved if they can not be made happy. Inpatients had to satisfied with the service given to them. Figure 3 summarized the structural analysis on path diagram.

Figure 3. Structured Path Coefficient Estimate

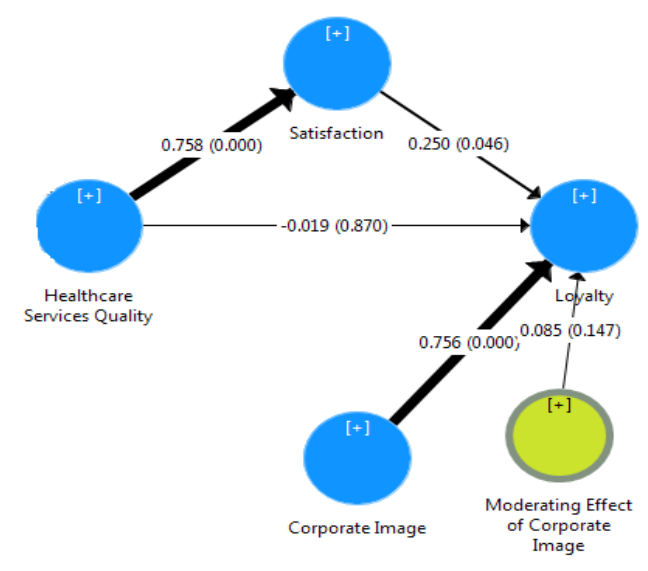

Our research showed that service quality had no significant effect toward loyalty. However, the service quality perceived by inpatients greatly affect their satisfaction. The degree of inpatients' satisfaction directly affected by their perception toward the service they experienced in the healthcare services. This satisfaction significantly improve their loyalty. If they can be satisfied enough, they tend to be loyal to the healthcare.

In order to achieve patients' loyalty, a better services are needed. However, it also required that the improved services have to be able to satisfy the customer. We already mentioned on literature review that each individual is unique. One perception may vary with the other. Thus, patient management may come in handy to provide better information to the service center as they adjust the services for the stated patients. The corporate image also positively affect their loyalty. Our findings support many other study which stated that corporate image will create people's loyalty. People tend to be more loyal to a reputable private healthcare service provider.

\section{The Moderation Effect of Brand Image}

In order to evaluate the moderation effect, we evaluate both model with interaction variable and without interaction variable. The first model (without interaction) can explained $70.2 \%$ variance in patients' loyalty (Adjusted R-squared $=$ 0.702). The second model (with interaction) can explain $70.9 \%$ variance in patients' loyalty (Adjusted R-squared $=0.709$ ). It is less than $1 \%$ increases for the adjusted R-squared value. In accordance with Hair's guide on evaluating moderation effect, there is no moderation effect of brand image in our model.

Based on significance analysis, there is significant effect of brand image toward loyalty. However the interaction with perceived service quality showed a positive non-significant effect. It is true that the brand image can slightly alter and can strengthen the effect of perceived service quality, however it is not significant. Thus, there is no moderation effect of brand image.

\section{CONCLUSION}

Our study showed that in order to create a loyal patient, the private healthcare services had to ensure that their services which were delivered to the patient can satisfy them. It is important to satisfy the patients. A great services will not improve their loyalty if it can not satisfy the patient. Moreover, improving the brand image is as important as improving the service quality. It should be in align the image on public and their service provided to the public.

Both service quality and brand image, based on our research are considered as two different variables that affect inpatients' loyalty. Brand image can not alter or strengthen the effect of service quality. Service quality is affecting inpatients' satisfaction before reached loyalty.

\section{ACKNOWLEDGMENT}

Authors gratefully acknowledge that the presented research is supported by Universitas Sumatera Utara (USU). This research is under research grant Non-PNBP USU 2017. 


\section{REFERENCES}

[1] I.A.W. Kesuma, D. Hadiwidjojo, N.L.P. Wiagustini, and F. Rohman, "Service quality influence on patient loyalty: Customer relationship management as mediation variable - Study on private hospital industry in Denpasar," International Journal of Business and Commerce, Volume 2, 1-14, August 2013

[2] Jamaluddin and E. Ruswanti, "Impact of service quality and customer satisfaction on customer loyalty: A case study in private hospital in Indonesia," IOSR Journal of Business and Management, Volume 19, 23-33, May 2017

[3] J. Wirtz, P. Chew, and C. Lovelock, Essentials of Services Marketing, 2nd Edition, Jurong: Pearson Education South Asia Pte Ltd, 2012

[4] A. Parasuraman, V.A. Zheitmal, and L.L. Berry, "SERVQUAL: A conceptual model of service quality and its implications for future research," Journal of Marketing, Volume 49, 41-50, 1985

[5] P. Kotler and K.L. Keller, Marketing Management, 14 Edition, New Jersey: Prentice Hall, 2012

[6] R.M. Al-Rousan, and B. Mohamed, "Customer loyalty and the impacts of service quality: The case of five star hotels in Jorda International", Journal of Business and Economic Sciences, Volume 5, 202-208, 2010

[7] K.H Liao, "Service quality and customer satisfaction: Direct and indirect effect in B2B customer loyalty framework", The Journal of Global Business Management, Volume 8, 2012

[8] J.T. Bowen and S.L. Chen, "The relationship between customer loyalty and customer satisfaction", International Journal of Contemporary Hospitality Management, Volume 13, 213-217, 2001

[9] K.O. Siddiqi, "Between service quality attributes, customer satisfaction and customer loyalty in the retail banking sector in Bangladesh", International Journal of Business and Management, Volume 6, 12-36, 2011

[10] A. Hsieh and C. Li, "The moderating effect of brand image on public relations perception and customer loyalty", Marketing Intelligence \& Planning, Volume 26, 26-42, 2008

[11] K. Chung, J. Yu, M. Choi, and J. Shin, "The effect of CSR on customer satisfaction and loyalty in China: The moderating role of corporate image", Journal of Economics, Business, and Management, Volume 3, 542-547, May 2015
[12] R. Mandhachitara and Y. Poolthong, "A model of customer loyalty and corporate social responsibility," Journal of Services Marketing, Volume 25,122-133, 2011

[13] A. Dick and K. Basu, "Customer loyalty: toward an integrated conceptual framework," Journal of Academy of Marketing Science, Volume 22, 99-113, 1994

[14] Jandahgi, "Studying the effect of brand loyalty on customer service Asian insurance company", Journal Business and Management, 2011

[15] C. Boshoff and B. Gray, "The relationships between service quality, customer satisfaction and buying intentions in the private hospital industry," South African Journal of Business Management, Volume 35, 27-37, 2004

[16] L. C. Ueltschy, M. Laroche, A. Eggert, and U. Bindl, "Service quality and satisfaction: An international comparison of professional services perceptions," Journal of Services Marketing, Volume 21, 410-423, 2007

[17] M. Edgar and F. Galia, "Why and how service quality perceptions impact consumer responses", Journal of Managing Service Quality, Volume 19, 474-485, 2009

[18] A. Parasuraman, V.A. Zheitmal, and L.L. Berry, "SERVQUAL: A multiple-item scale for measuring consumer perceptions of service quality", Journal of Retailing, Volume 64, 12-40, 1988

[19] A.N. Lubis, P. Lumbanraja, R.R. Lubis, and B.K. Hasibuan, "Factor analysis of healthcare service quality in Medan's government hospital", Journal of Ponte, Volume 72, 131-141, 2016

[20] Y. Jiang, and C.L. Wang, "The impact of affect on service quality and satisfaction: the moderation of service contexts", Journal of Services Marketing, Volume 20, 211-218, 2006

[21] S. Ahmed, K.M. Tarique, I. Arif, "Service quality, patient satisfaction and loyalty in the Bangladesh healthcare sector", International Journal of Health Care Quality Assurance, Volume 30, 477-488, 2017

[22] G.R. Dowling, "Journalists' evaluation of corporate reputations," Corporate Reputation Review, Volume 7, 1-205, 2004

[23] R. Dolphin, "Corporate reputation - a value creating strategy", Corporate Governance 4, 77-92, 2004

[24] C.M. Ringle, S. Wende, and J.M. Becker, SmartPLS 3, Boenningstedt: SmartPLS, http:www.smartpls.com

[25] J.F. Hair Jr., G. Hult, C.M. Ringle, and M.Sarstedt, A Primer on Partial Least Squares Structural Equation Modeling (PLS-SEM), United States of America: SAGE Publications, Inc., 2014 